\section{Harvest Date Effects on Maturity, Quality, and Storage Disorders of 'Honeycrisp' Apples}

\author{
Christopher B. Watkins, ${ }^{1}$ Mustafa Erkan, ${ }^{2}$ and Jacqueline F. Nock \\ Department of Horticulture, Cornell University, Ithaca, NY 14853
}

\author{
Kevin A. Iungerman \\ Cornell Cooperative Extension, Ballston Spa, NY 55108
}

Randolph M. Beaudry

Department of Horticulture, Michigan State University, East Lansing, MI 48824

\section{Renae E. Moran}

Department of Plant, Soil and Environmental Sciences, Monmouth, ME 02459

Additional index words. Malus sylvestris var. domestica, soggy breakdown, soft scald, maturity, ethylene

\begin{abstract}
Honeycrisp' is a new apple [Malus sylvestris (L.) Mill. var. domestica (Borkh.) Mansf.] cultivar that has been planted extensively in North America, but the storage disorders soggy breakdown and soft scald have resulted in major fruit losses. The effects of harvest date and storage temperature on fruit quality and susceptibility of fruit to these disorders have been investigated in Michigan, New York, and Maine. Internal ethylene concentrations were variable over a wide range of harvest dates, and a rapid increase in autocatalytic ethylene production was not always apparent. The starch pattern index, soluble solids content, titratable acidity and firmness also appear to have limited use as harvest indices. Development of soggy breakdown and soft scald is associated with later harvest dates and storage of fruit at temperatures of 0 to $0.5{ }^{\circ} \mathrm{C}$ compared with higher storage temperatures. It is recommended that 'Honeycrisp' be stored at $3{ }^{\circ} \mathrm{C}$, although storage disorders still can occur at this temperature if fruit are harvested late. In addition, greasiness development may be worse at higher storage temperatures.
\end{abstract}

'Honeycrisp' apple [Malus sylvestris (L.) Mill. var. domestica (Borkh.) Mansf.] fruit are susceptible to the storage disorders soggy breakdown, soft scald, and bitter pit. The cultivar, released by the Minnesota Agricultural Experiment Station in 1991, has been widely planted in the United States with about 950,000 trees planted as of January 2001 (Tong et al., 2003). 'Honeycrisp' has outstanding flavor characteristics, and it has been reported to remain crisp during air storage for 9 months (Luby and Bedford, 1992; Tong et al., 1999). Initial enthusiasm for 'Honeycrisp' Received for publication 18 May 2004. Accepted for publication 30 June 2004. This research was supported by the New York Apple Research and Development Program, the Michigan State Horticultural Society and the Michigan Apple Research Committee, the Maine Agricultural Center, University of Maine, a grant to Mustafa Erkan from a ICSC-World Laboratory Scholarship, and the Cornell University and Michigan State University Agricultural Experiment Station federal formula funds, Project No. NE-1018, received from the Cooperative State Research, Education and Extension Service, U.S. Department of Agriculture. Any opinions, findings, conclusions, or recommendations expressed in this publication are those of the authors and do not necessarily reflect the view of the U.S. Department of Agriculture.

${ }^{1}$ To whom reprint requests should be addressed; e-mail cbw3@cornell.edu.

${ }^{2}$ Current address: Department of Horticulture, Faculty of Agriculture, Akdeniz University, 07059 Antalya, Turkey. by the apple industry, however, has been tempered by concern about high incidences of physiological disorders in the fruit (Greene and Weis, 2001; Rosenberger et al., 2001), as well as stem punctures, stem end splitting and decay (Wargo and Watkins, 2004). Bitter pit is a calcium-related disorder (Ferguson and Watkins, 1989) that can occur on the tree or develop during storage, but its incidence can be reduced by management practices such as calcium spray application (Rosenberger et al., 2004). In contrast, the occurrence of soft scald, soggy breakdown, and associated fermentative marketplace, resulting in loss of confidence in the cultivar.

The symptoms of soft scald (syn. deep scald or ribbon scald) are the development of sharply defined brown lesions on the skin of the apple, which can extend into the flesh (Brooks and Harley, 1934; Pierson et al., 1971; Snowden, 1990; Watkins and Rosenberger, 2002). Susceptible cultivars include 'Fuji', 'Jonathan', 'McIntosh', 'Delicious', and 'Golden Delicious'. Soggy breakdown is an internal disorder, and in worst cases a complete ring of soft, brown, spongy tissue is present (Smock and Neubert, 1950; Watkins and Rosenberger, 2002). The causes of soggy breakdown may be identical, even if different in expression, with soft scald (Plagge et al., 1935; Plagge and Maney, 1937), but cultivars that are susceptible to soggy breakdown are off-flavors in the fruit has been erratic in the not always susceptible to soft scald. Both soft scald and soggy breakdown are thought to be forms of low temperature injury, being worse in fruit stored below 2 to $3{ }^{\circ} \mathrm{C}$. In cultivars susceptible to both disorders, one disorder may occur without the other or both can be present in the same fruit.

Major disposing factors that have been implicated in the occurrence of soft scald in several apple cultivars are over-maturity of fruit at harvest (Brooks and Harley, 1934) and preharvest factors such as climate (dull, cool, wet summers), light crops, large fruit, and vigorous soils (Smock, 1950; Snowden, 1990). A recent study by Tong et al. (2003) indicated that susceptibility of 'Honeycrisp' fruit to soft scald was affected by maturity, being greater in the second of two harvest dates, but was not associated with internal ethylene concentrations (IEC) in the fruit. However, little information exists describing the ontogeny of harvest indices and the relationship of these to storage performance for 'Honeycrisp'. Growing location also appears to be a factor (Tong et al., 2003), but it is not clear if the effects of delays in cooling among sites was a factor in that experiment (Watkins et al., 2004). The objective of the present study was to investigate harvest date effects on quality and storage temperature relationships with fruit susceptibility to soft scald and soggy breakdown.

\section{Materials and Methods}

Michigan. 'Honeycrisp' fruit were harvested twice weekly for 5 weeks from a commercial orchard in the Fruit Ridge area of Michigan in 1998. The trees were planted on M-9 rootstocks in 1996. On each date, 60 fruit were transported to Michigan State University on the day of harvest. Analysis of IEC, fruit firmness, background color, fruit size, percent red coloration, and starch index were performed one day after harvest on 10 randomly selected fruit. Fruit firmness after $7 \mathrm{~d}$ at $20^{\circ} \mathrm{C}$ was also determined on an additional 10 fruit.

The remaining 40 fruit were screened for defects and 35 to 39 defect-free fruit from each harvest were stored for 3.5 months in refrigerated air storage at $0{ }^{\circ} \mathrm{C}$. Fruit were stored in $20-\mathrm{L}$ plastic pails, each fitted with lids with a $3 \mathrm{~cm}$ diameter hole for aeration to minimize moisture loss. About 20 fruit were stored in each pail. After storage, fruit were allowed to warm to room temperature overnight and the next day the number of fruit displaying external symptoms of soft scald and decay were recorded. The data are reported as percent fruit affected. Fruit firmness was determined on 10 fruit lacking external symptoms of scald and having minimal decay.

New York. In the 2000 harvest season, three orchard blocks were chosen in the Champlain region. These trees ranged from 3 to 5 years old and were grafted on M.26 (blocks 1 and 2) or Bud 9 (block 3). Fruit were harvested from a minimum of 10 trees in each block on 14,21 , and 28 Sept. The most commercially mature fruit were harvested on each occasion as judged by blush area, usually $>80 \%$. In the 
2001 harvest season, two of the orchard blocks used in 2000 were used for the experiments, and fruit were harvested on 10, 17, and 24 Sept. and 1 Oct.

At each harvest, two replicate samples of 10 fruit were used for assessment of fruit maturity and quality. IEC, starch index, firmness, and SSC were measured in 2000 and 2001. Titratable acidity was measured only in 2000 .

A further 50 to 80 fruit were harvested, placed into perforated plastic bags, and stored in refrigerated air on the day of harvest at 0.5 or $2.8^{\circ} \mathrm{C}(2000)$, and $0.5,3.3$, and $5^{\circ} \mathrm{C}(2001)$, for 12 weeks (2000) and 16 weeks (2001). Fruit quality after storage was assessed on 10-fruit samples free of disorders after a further 1 or $7 \mathrm{~d}$ at $20^{\circ} \mathrm{C}$. IEC, firmness, titratable acidity and SSC were measured in 2000 and 2001, while only firmness was measured in 2000 . The remaining fruit were assessed externally and internally for disorders.

In 2001, ethylene production of individual fruit was determined on 5 fruit harvested on 10, 17, and 24 Sept. and 1 Oct. Fruit were sealed daily in 1-L containers for $2 \mathrm{~h}$ for 10 $\mathrm{d}$ and headspace measurements of ethylene concentration were determined by gas chromatography as described below.

Maine. Fruit were obtained from 'Honeycrisp' trees grafted onto M.26 EMLA located at the Agricultural Experiment Station in Monmouth, Maine. The orchard was blocked by location with five blocks and four trees within each block. Tree age was 8 years in 2002 and nine years in 2003. Crop load was moderate in 2002 and heavy in 2003. Harvest dates were based on commercial harvest periods in Maine, one to two weeks before commercial harvest, at the start of commercial harvest, and 1 to 2 weeks later. Fruit were harvested on 13 and 25 Sept. and 7 Oct. 2002, and 19 and 29 Sept. and 8 Oct. 2003, and placed in refrigerated air storage on the day of harvest, except for 7 Oct. 2002 when they remained out of cold storage for about 1 day. Storage temperatures were $1{ }^{\circ} \mathrm{C}$ for all harvest dates, and $3{ }^{\circ} \mathrm{C}$ for the $25 \mathrm{Sept}$. and 7 Oct., 2002 and 29 Sept., 2003 harvest dates. Humidity was not measured.

At each harvest date, 50 fruit were harvested from each group of four trees. Starch index, IEC and flesh firmness were measured on ten fruit at each harvest date. Fruit were removed from storage after 5 months. After storage, fruit were held at $20{ }^{\circ} \mathrm{C}$ for 1 and $7 \mathrm{~d}$, after which firmness and IEC were measured on ten sound fruit. The IEC was measured only after one day at $20^{\circ} \mathrm{C}$ in 2003 . Occurrence of disorders was measured after $7 \mathrm{~d}$ at $20^{\circ} \mathrm{C}$ on 40 fruit in 2002 and 20 fruit in 2003.

Assays. The IEC was determined by withdrawing a 1-mL gas sample from the core of each apple fruit using a 1-mL plastic syringe. Samples were analyzed by gas chromatography in all locations, but using different gas chromatographs. In Michigan, a Carle Series 400 (AGC Hach Co., Loveland, Colo.) fitted with a 2-m-long, 2-mm-i.d. stainless-steel column packed with activated alumina was used; detection was via a flame ionization detector (FID). In New York, a Hewlett Packard 5890 series II (Hewlett Packard Co., Wilmington,
Del.) equipped with a stainless-steel column packed with 60/80 mesh alumina F-1 (2-m $\times$ 2-mm, i.d.) and a FID was used. In Maine, a Shimadzu GC-8A (Shimadzu, Kyoto, Japan) fitted with a $450 \times 3$-mm stainless-steel column packed with activated alumina and a FID was used.

The starch index at harvest was determined in all three geographical regions by cutting fruit in half through the seed cavity and dipping the cut surface of one of the halves into a solution containing $10 \mathrm{~g} \mathrm{KI}$ and $2.2 \mathrm{~g} \mathrm{I}_{2}$ per $\mathrm{L}$ of water. The starch index was rated according to the Cornell Starch Chart (Blanpied and Silsby, 1992) where $1=100 \%$ staining and 8 $=0 \%$ staining.

Percent blush (red coloration) was estimated visually. Background color was determined on a scale of 5 (green) to 1 (yellow) by comparison to the Cornell color chart for McIntosh (Anon., 1948). Firmness of fruit was measured on opposite pared sides of each fruit using an 11.1-mm-diameter probe. In Michigan, firmness was measured manually using a drill stand-mounted penetrometer (Effegi FT-327, McCormick Fruit Tree Inc., Yakima, Wash.) while in New York and Maine, firmness was measured using a mechanized pressure tester (EPT-1, Lake City Tech. Products, Lake City, Canada) and the expressed juice used for SSC measurement with a refractometer (Atago PR-100, Atago Co., Ltd., Tokyo, Japan). Titratable acidity was measured on juice extracted from composite samples of segments using $0.1 \mathrm{M} \mathrm{NaOH}$ to an end point of $\mathrm{pH} 8.1$ with an autotitrator (Mettler DL12, Hightstown, N.J.).

In 2001, New York-grown fruit from the four harvests and three storage temperatures were evaluated by quantitative descriptive analysis (Shewfelt, 1993) using an untrained panel of 27 growers. Panelists were asked to rate apples from each treatment for appearance, texture, flavor, and overall acceptability. A horizontal line with linear equal interval scales from 1 to 9 , where $1=$ poor and $9=$ excellent, was provided on the evaluation sheet for each attribute. Data were obtained by measuring the unit value for each attribute.

Statistical analyses. Data were analyzed by

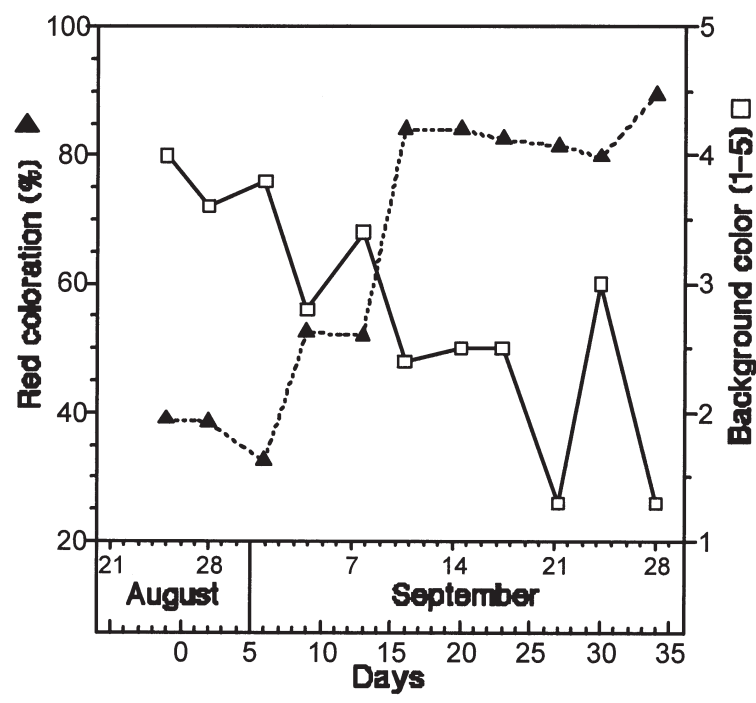

analysis of variance (ANOVA) via the general linear models procedure using commercial software (Minitab software v 11.12, Minitab, Inc., State College, Pa). Disorder percentages were arcsine-transformed before analysis. The least significant difference procedure at $P=0.05$ was used to test differences in treatment means.

\section{Results}

Michigan. Percent red coloration increased from an initial $40 \%$ blush to $80 \%$ blush, with the most rapid increase occurring over a 2week-long period in early September (Fig. $1)$. The change in background color was more gradual, declining throughout the study from an initial high of 4 units to near 1 unit by late September. The IEC was $<1 \mu \mathrm{L} \cdot \mathrm{L}^{-1}$ for the first five harvests (Fig. 2). After 9Sept. (day 14), the IEC started to increase but remained below 15 $\mu \mathrm{L} \cdot \mathrm{L}^{-1}$ until it increased to $70 \mu \mathrm{L} \cdot \mathrm{L}^{-1}$ at the last harvest (29 Sept.). The initiation of an increase in IEC coincided with a starch index of about 3. Average firmness ranged between 75.5 and $104 \mathrm{~N}, 76.1$ and $99.2 \mathrm{~N}$, and 84.1 and $99.7 \mathrm{~N}$ across all harvests for fruit $1 \mathrm{~d}$ after harvest, 7 $\mathrm{d}$ after harvest, and after $90 \mathrm{~d}$ air storage at 0 ${ }^{\circ} \mathrm{C}$, respectively, with no clear trend apparent (data not shown).

After storage, soft scald incidence was between $10 \%$ and $20 \%$ for harvests before the onset of the increase in IEC (Fig. 2). For harvests after the initial increase in the IEC, soft scald incidence increased to over $60 \%$ on 23 Sept. (day 28), then declined for the last two harvests. Decay exhibited a similar trend, increasing in harvests occurring after the IEC began to increase until 23 Sept. and declining for the last two harvests. Much of the decay was associated with the lesions caused by soft scald, so the close association of decay with soft scald incidence is likely a result of pathogens attacking compromised or dead tissue.

New York. Fruit were harvested on three occasions from three orchards in 2000, and stored at 0.5 or $2.8^{\circ} \mathrm{C}$. On the 14 Sept. harvest, fruit were climacteric, as indicated by IECs that were $>1 \mu \mathrm{L} \cdot \mathrm{L}^{-1}$, in two of the three orchards, being highest in orchard block 1 (Table 1). However, by 21 Sept., the IEC did not increase in orchard block 1 , and increased only slightly in the other orchard blocks. On the last sampling date, the IEC of fruit from all blocks decreased relative to the previous harvest date. The starch index increased over time, but significant differences among orchard blocks were not detected for the second and third harvest dates. Firmness decreased over time, although there were differences in firmness among the three orchard blocks. SSC was not affected by harvest date, but varied

Fig. 1. Influence of harvest date on percent red coloration and background color ( $5=$ green, $1=$ yellow $)$ at harvest for 'Honeycrisp' apples from Michigan in $1998(\mathrm{n}=10)$. 

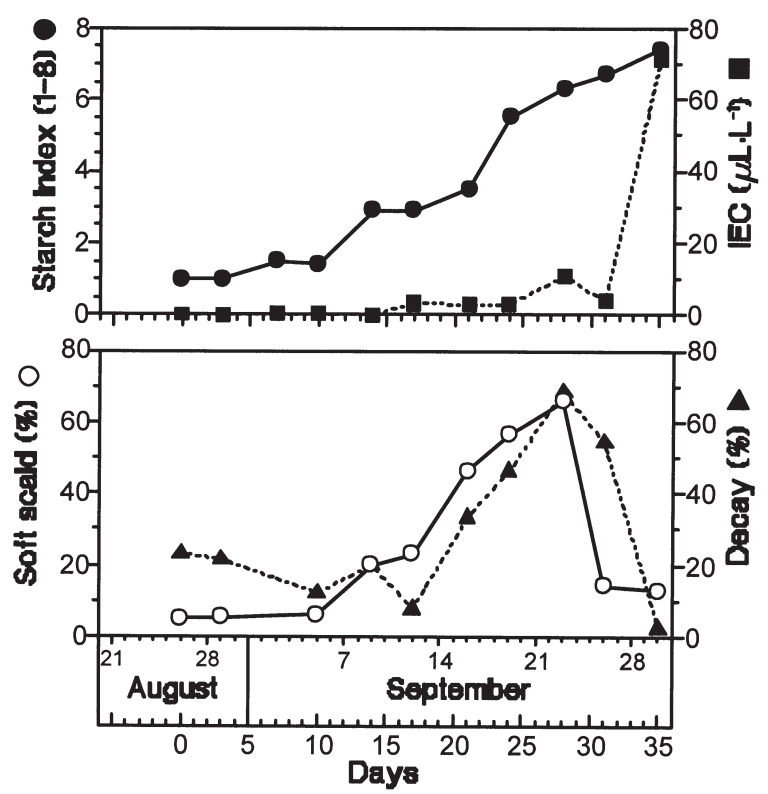

Fig. 2. Influence of harvest date on internal ethylene concentration and starch index at harvest $(n=10)$, and decay and soft scald incidence after 3 months refrigerated air storage at $0{ }^{\circ} \mathrm{C}(\mathrm{n}=35$ to 39$)$ for 'Honeycrisp' apples from Michigan in 1998.

$0.5^{\circ} \mathrm{C}$ and after $7 \mathrm{~d}$ than after 1 d (Table 2). Firmness and SSC were not affected by any factor, and titratable acidity decreased with advancing harvest date and shelf life period.

The incidences of soft scald and soggy breakdown after storage were affected by harvest date and storage temperature (Table 3). Because within orchard block replication was not used, it is not possible to determine the significance of among-block differences. Nevertheless, the

by orchard block. Titratable acidity decreased over time, but the higher acidity of fruit from orchard block 1 compared with the other fruit was not consistently significant.

After storage, IEC was not affected by harvest date but was higher at $2.8^{\circ} \mathrm{C}$ than at

Table 1. Internal ethylene concentrations (IEC), starch index, firmness, soluble solids content (SSC) and titratable acidity in 'Honeycrisp' apples harvested in the Champlain Valley, N.Y., on 14, 21, and 28 Sept. 2000

\begin{tabular}{|c|c|c|c|c|c|c|}
\hline $\begin{array}{l}\text { Harvest } \\
\text { date }\end{array}$ & $\begin{array}{l}\text { Orchard } \\
\text { block }\end{array}$ & $\begin{array}{c}\text { IEC } \\
\left(\mu \mathrm{L} \cdot \mathrm{L}^{-1}\right)\end{array}$ & $\begin{array}{l}\text { Starch } \\
\text { index } \\
(1-8)\end{array}$ & $\begin{array}{l}\text { Firmness } \\
\text { (N) }\end{array}$ & $\begin{array}{l}\mathrm{SSC} \\
(\%)\end{array}$ & $\begin{array}{c}\text { Titratable } \\
\text { acidity } \\
\text { (\% malic acid) }\end{array}$ \\
\hline \multirow[t]{4}{*}{14 Sept. } & 1 & 24.4 & 5.7 & 66.6 & 13.1 & 0.57 \\
\hline & 2 & 0.4 & 4.6 & 61.2 & 11.0 & 0.41 \\
\hline & 3 & 3.0 & 4.8 & 69.1 & 11.7 & 0.44 \\
\hline & Harvest average & 9.3 & 5.0 & 65.6 & 11.9 & 0.47 \\
\hline \multirow[t]{4}{*}{21 Sept. } & 1 & 29.2 & 6.0 & 65.3 & 12.6 & 0.42 \\
\hline & 2 & 13.8 & 5.5 & 59.3 & 11.5 & 0.33 \\
\hline & 3 & 12.4 & 5.9 & 64.5 & 11.8 & 0.40 \\
\hline & Harvest average & 18.5 & 5.8 & 63.0 & 11.9 & 0.38 \\
\hline \multirow[t]{4}{*}{28 Sept. } & 1 & 1.9 & 6.8 & 60.5 & 12.9 & 0.38 \\
\hline & 2 & 7.1 & 7.2 & 54.7 & 11.3 & 0.27 \\
\hline & 3 & 3.6 & 6.7 & 61.3 & 12.6 & 0.33 \\
\hline & Harvest average & 4.2 & 6.9 & 58.8 & 12.3 & 0.33 \\
\hline \multicolumn{7}{|l|}{ Significance } \\
\hline Harvest date $(\mathrm{H})$ & & $* * *$ & $* * *$ & $* * *$ & NS & $* * *$ \\
\hline Orchard block (O) & & $* * *$ & $*$ & $* * *$ & $* * *$ & $* * *$ \\
\hline $\mathrm{H} \times \mathrm{O}$ & & $* * *$ & $* *$ & NS & NS & $*$ \\
\hline
\end{tabular}

NS,*,**,**** Nonsignificant or significant at $P \leq 0.05,0.01$ or 0.001 , respectively.

Table 2. Internal ethylene concentration (IEC), firmness, soluble solids content (SSC), and titratable acidity of 'Honeycrisp' apples harvested in the Champlain Valley, N.Y., on 14, 21, and 28 Sept. 2000, and stored at 0.5 or $2.8^{\circ} \mathrm{C}$ for 12 weeks plus $7 \mathrm{~d}$ at $20^{\circ} \mathrm{C}$.

\begin{tabular}{|c|c|c|c|c|}
\hline $\begin{array}{l}\text { Main } \\
\text { effects }\end{array}$ & $\begin{array}{c}\mathrm{IEC} \\
\left(\mu \mathrm{L} \cdot \mathrm{L}^{-1}\right)\end{array}$ & $\begin{array}{l}\text { Firmness } \\
\text { (N) }\end{array}$ & $\begin{array}{l}\text { Soluble } \\
\text { solids } \\
(\%)\end{array}$ & $\begin{array}{c}\text { Titratable } \\
\text { acidity } \\
\text { (\% malic acid })\end{array}$ \\
\hline \multicolumn{5}{|l|}{ Harvest date } \\
\hline 14 Sept. & 63.1 & 63.9 & 12.3 & 0.30 \\
\hline 21 Sept. & 63.2 & 60.9 & 12.4 & 0.28 \\
\hline 28 Sept. & 58.3 & 57.7 & 12.1 & 0.24 \\
\hline Significance & NS & $* * *$ & NS & $* *$ \\
\hline \multicolumn{5}{|l|}{ Temperature } \\
\hline $0.5^{\circ} \mathrm{C}$ & 51.9 & 61.2 & 12.4 & 0.28 \\
\hline $2.8^{\circ} \mathrm{C}$ & 71.2 & 60.5 & 12.1 & 0.26 \\
\hline Significance & $* *$ & NS & NS & NS \\
\hline \multicolumn{5}{|l|}{ Shelf life } \\
\hline $1 \mathrm{~d}$ & 10.8 & 60.3 & 12.4 & 0.29 \\
\hline $7 \mathrm{~d}$ & 112.3 & 61.3 & 12.8 & 0.25 \\
\hline Significance & $* * *$ & NS & NS & $* *$ \\
\hline
\end{tabular}

NS,**,***Nonsignificant or significant at $P \leq 0.01$ or 0.001 , respectively.
${ }^{\circ} \mathrm{C}$. Even at the 28 Sept. harvest, the increased incidence, while averaging 39\%, was lower at $2.8^{\circ} \mathrm{C}$ than at $0.5^{\circ} \mathrm{C}$ (Table 3). Bitter pit and decay incidences were not affected by harvest date (although fruit could not be assessed on 28 Sept. because of the high soft scald and soggy breakdown incidences), or temperature. The percentage of greasy fruit was higher at the 21 Sept. harvest than the 14 Sept. harvest, and at $2.8^{\circ} \mathrm{C}$ compared with $0.5^{\circ} \mathrm{C}$.

In 2001, fruit were harvested from two orchards and stored at $0.5,3.3$, or $5.0^{\circ} \mathrm{C}$ for 16 weeks. At harvest, the overall IEC differed $(P \leq 0.05)$ between orchards, averaging 9.6 and $7.5 \mu \mathrm{L} \cdot \mathrm{L}^{-1}$ for orchard 1 and 2 , respectively. The IEC differed among harvest dates $(P \leq$ 0.001 ) averaging $7.3,5.4,12.4$, and $9.1 \mu \mathrm{L} \cdot \mathrm{L}^{-1}$ for harvests on 10, 17, and 24 Sept. and 1 Oct., respectively. However, no interaction between orchard block and harvest date was detected. The starch index was not affected by orchard block, but increased over harvest date $(P \leq 0.001)$ averaging 5.8, 6.8, 7.5, and 7.7 units for harvests on 10,17 , and 24 Sept. and 1 Oct., respectively. For starch, an interaction between orchard block and harvest date was detected $(P \leq 0.05)$ with differences between fruit from the orchards occurring only at harvest 1 . Fruit softened with advancing harvest date, being 65.1, 60.9, 59.8, and $54.0 \mathrm{~N}$ for harvests on 10, 17, and 24 Sept. and 1 Oct., respectively; an interaction was also detected $(P \leq 0.01)$, however, with fruit from orchard 2 being firmer than those from orchard 1 on all harvest dates except on 1 Oct. SSC was affected by orchard block but not by any other factor (data not shown).

Ethylene production of fruit from one orchard was also measured over time at 20 ${ }^{\circ} \mathrm{C}$ for each harvest (Fig. 3). A significant harvest date $\times$ days at $20{ }^{\circ} \mathrm{C}$ interaction was detected in $2001(P \leq 0.001)$. Fruit from the 1 Oct. harvest date had the highest maximum production, but essentially similar changes in ethylene production were found over time for all harvest dates.

No effect of storage temperature on firmness was detected (data not shown), although firmness declined with advancing harvest date; average firmness was $62.1,58.5,56.4$, and 53.8 $\mathrm{N}$ for fruit harvested on 10,17 , and 24 Sept. and 1 Oct., respectively. However, fruit evaluations using an untrained panel found that the only factor that was affected significantly by harvest date was attractiveness of appearance (Table 4), which increased as the harvest date was delayed. Over all harvest dates, flavor and overall acceptability was highest for fruit stored at $3.3{ }^{\circ} \mathrm{C}$. Comments indicated that this was due mainly to alcoholic off-flavors in fruit at $0.5{ }^{\circ} \mathrm{C}$ and lack of flavor at $5{ }^{\circ} \mathrm{C}$.

Soft scald and soggy breakdown occurred in fruit from the $10 \mathrm{Sept}$. harvest only at $0.5^{\circ} \mathrm{C}$, but were present in fruit stored at both 0.5 and $3.3^{\circ} \mathrm{C}$ from the other harvests (Table 5). While incidence of both disorders was lower at $3.3{ }^{\circ} \mathrm{C}$ than at 0.5 ${ }^{\circ} \mathrm{C}$, disorder incidence was high even at $3.3^{\circ} \mathrm{C}$. Fruit kept at $5.0^{\circ} \mathrm{C}$ had essentially no incidence of either disorder but did have higher, though variable, rot incidence. Bitter pit incidence was affected by harvest date and storage temperature, but not in a consistent fashion. 


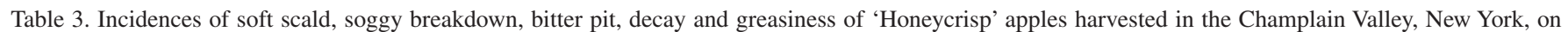
14,21 , and 28 Sept. 2000 and stored in air at 0.5 or $2.8^{\circ} \mathrm{C}$ for 12 weeks. Fruit $(\mathrm{n}=50-80)$ were evaluated after a further $7 \mathrm{~d}$ at $20{ }^{\circ} \mathrm{C}$. Means are shown as back-transformed data after analysis of arcsine-transformed data.

\begin{tabular}{|c|c|c|c|c|c|c|c|c|c|c|c|}
\hline \multirow{2}{*}{$\begin{array}{l}\text { Harvest } \\
\text { date }\end{array}$} & \multirow{2}{*}{$\begin{array}{l}\text { Orchard } \\
\text { block }\end{array}$} & \multicolumn{2}{|c|}{$\begin{array}{c}\text { Soft } \\
\text { scald } \\
(\%)\end{array}$} & \multicolumn{2}{|c|}{$\begin{array}{c}\text { Soggy } \\
\text { breakdown } \\
(\%)\end{array}$} & \multicolumn{2}{|c|}{$\begin{array}{c}\text { Bitter } \\
\text { pit } \\
(\%) \\
\end{array}$} & \multicolumn{2}{|c|}{$\begin{array}{c}\text { Decay } \\
(\%)\end{array}$} & \multicolumn{2}{|c|}{$\begin{array}{c}\text { Greasiness } \\
(\%)\end{array}$} \\
\hline & & $0.5^{\circ} \mathrm{C}$ & $2.8^{\circ} \mathrm{C}$ & $0.5^{\circ} \mathrm{C}$ & $2.8^{\circ} \mathrm{C}$ & $0.5^{\circ} \mathrm{C}$ & $2.8^{\circ} \mathrm{C}$ & $0.5^{\circ} \mathrm{C}$ & $2.8^{\circ} \mathrm{C}$ & $0.5^{\circ} \mathrm{C}$ & $2.8^{\circ} \mathrm{C}$ \\
\hline \multirow[t]{4}{*}{14 Sept. } & 1 & 12 & 3 & 18 & 3 & 15 & 13 & 0 & 10 & 0 & 55 \\
\hline & 2 & 3 & 0 & 3 & 0 & 0 & 0 & 0 & 0 & 5 & 44 \\
\hline & 3 & 0 & 0 & 0 & 0 & 6 & 0 & 0 & 0 & 10 & 57 \\
\hline & Harvest average & 5 & 1 & 7 & 1 & 7 & 4 & 0 & 3 & 5 & 52 \\
\hline \multirow[t]{4}{*}{21 Sept. } & 1 & 52 & 0 & 52 & 0 & 33 & 54 & 7 & 5 & 56 & 82 \\
\hline & 2 & 26 & 0 & 33 & 0 & 9 & 13 & 0 & 0 & 20 & 56 \\
\hline & 3 & 58 & 3 & 64 & 3 & 8 & 8 & 0 & 0 & 25 & 53 \\
\hline & Harvest average & 45 & 1 & 49 & 1 & 17 & 25 & 2 & 3 & 34 & 64 \\
\hline \multirow[t]{4}{*}{28 Sept. } & 1 & 97 & 42 & 97 & 42 & $\mathrm{ND}^{\mathrm{z}}$ & ND & ND & ND & ND & ND \\
\hline & 2 & 78 & 48 & 78 & 48 & ND & ND & ND & ND & ND & ND \\
\hline & 3 & 70 & 28 & 70 & 28 & ND & ND & ND & ND & ND & ND \\
\hline & Harvest average & 82 & 39 & 82 & 39 & & & & & & \\
\hline \multicolumn{12}{|l|}{ Significance } \\
\hline Harvest date $(\mathrm{H})$ & & \multicolumn{2}{|c|}{$* * *$} & \multicolumn{2}{|c|}{$* * *$} & \multicolumn{2}{|c|}{ NS } & \multicolumn{2}{|c|}{ NS } & \multicolumn{2}{|c|}{$*$} \\
\hline Temperature $(\mathrm{T})$ & & \multicolumn{2}{|c|}{$* * *$} & \multicolumn{2}{|c|}{$* * *$} & \multicolumn{2}{|c|}{ NS } & \multicolumn{2}{|c|}{ NS } & \multicolumn{2}{|c|}{$* * *$} \\
\hline $\mathrm{H} \times \mathrm{T}$ & & \multicolumn{2}{|c|}{$* *$} & \multicolumn{2}{|c|}{$* *$} & \multicolumn{2}{|c|}{ NS } & \multicolumn{2}{|c|}{ NS } & \multicolumn{2}{|c|}{ NS } \\
\hline
\end{tabular}

${ }^{\mathrm{z}} \mathrm{ND}=$ not detectable because of high soft scald incidence. ANOVA for harvest date and temperature performed only on 14 and 21 Sept. harvest dates. NS, ***,****Nonsignificant or significant at $P \leq 0.05,0.01$ or 0.001 , respectively.

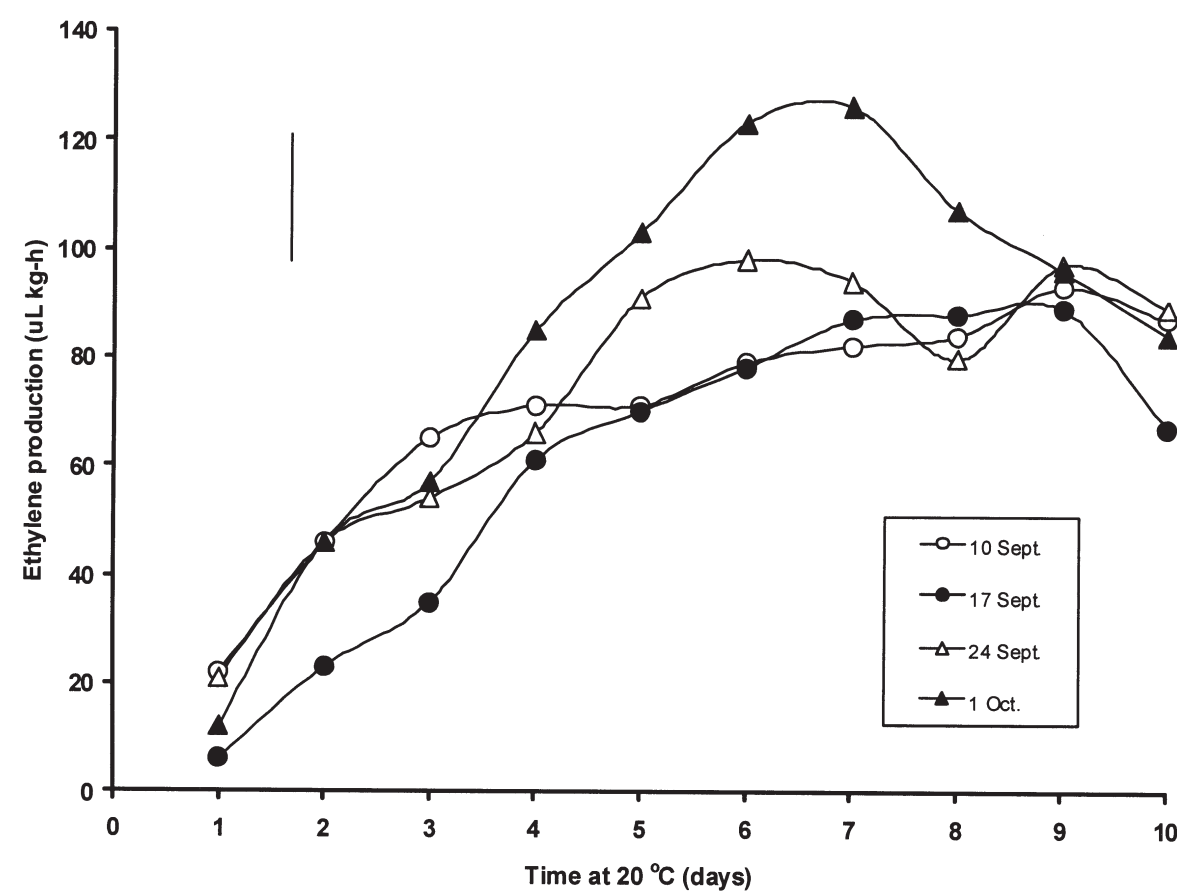

Fig. 3. Ethylene production of 'Honeycrisp' apples harvested on 10, 17, and 24 Sept. and 1 Oct. 2001, and kept at $20^{\circ} \mathrm{C}$ for $10 \mathrm{~d}$. Vertical line represents the LSD at $P=0.05$.

Maine. The IEC was undetectable at the first harvest in 2002 when starch index was below 4.8, and was $0.1 \mu \mathrm{L} \cdot \mathrm{L}^{-1}$ in 2003 when starch index was 5.5. The IEC rose to a peak of $6.5 \mu \mathrm{L} \cdot \mathrm{L}^{-1}$ with the second harvest in 2002 , when starch index was 6.9. In 2003, it rose to a peak of $31.7 \mu \mathrm{L} \cdot \mathrm{L}^{-1}$ when starch index was 7.8. With the last harvest, IEC fell to an undetectable level in 2002, and also fell to 4.4 $\mu \mathrm{L} \cdot \mathrm{L}^{-1}$ in 2003 . In both years, the third harvest occurred at a starch index of 8 or when there was little or no starch remaining in fruit.

In 2002, IEC after storage was affected by harvest date and storage temperature with an interaction between the two (Table 6). In fruit stored at $1{ }^{\circ} \mathrm{C}$, there was no difference in IEC between the three harvest dates. However, when fruit harvested on 25 Sept. were at 3 ${ }^{\circ} \mathrm{C}$, IEC was greater than when stored at $1{ }^{\circ} \mathrm{C}$ and greater than when harvested 7 Oct. and subsequently stored at either 1 or $3{ }^{\circ} \mathrm{C}$. The IEC was measured again after fruit were held for $7 \mathrm{~d}$ at $20^{\circ} \mathrm{C}$; IEC increased only for fruit harvested 25 Sept. (data not shown). In 2003, fruit harvested on 29 Sept. and stored at $3{ }^{\circ} \mathrm{C}$ had a greater IEC than when stored at $1{ }^{\circ} \mathrm{C}$.

In 2002, flesh firmness was affected by harvest date, but not by storage temperature. Stored fruit harvested on 13 Sept. were firmest, 25 Sept. intermediate, and 7 Oct. the least firm. In 2003, flesh firmness was affected by harvest date with fruit harvested 8 Oct. being softer than earlier harvest dates. Storage temperature did not affect firmness of fruit harvested 29 Sept.
SSC was not affected by harvest date or storage temperature in 2002. In 2003, fruit harvested on 8 Oct. had greater SSC than fruit harvested at earlier dates. Storage temperature did not affect SSC in fruit harvested on 29 Sept.

In 2002, harvest date and storage temperature affected the occurrence of soft scald with an interaction between the two factors (Table 6). Soft scald incidence was greater for fruit harvested on $25 \mathrm{Sept}$. compared with an earlier or later harvest date. Storage at $3{ }^{\circ} \mathrm{C}$ resulted in less soft scald than storage at $1^{\circ} \mathrm{C}$, and this occurred with harvest 25 Sept., but not with harvest at 7 Oct. Storage temperature did not affect soft scald occurrence in fruit harvested 7 Oct. In 2003, harvest date and storage temperature did not affect the occurrence of soft scald, but little soft scald occurred in this year. Occurrence of soggy breakdown was rare in both years with $<1 \%$ of the fruit being affected (data not shown). However, flesh browning, which unlike soggy breakdown, is a diffuse light-colored browning of the flesh, was affected by harvest date but not by storage temperature in 2002. Harvest on 7 Oct. resulted in more fruit being affected than with earlier harvest dates. In 2003, harvest date and storage temperature did not affect occurrence of flesh browning.

In 2002, bitter pit was less prevalent on the 25 Sept. harvest date compared with earlier and later harvest dates. Storage temperature did not affect the occurrence of bitter pit. In 2003, bitter pit was not affected by harvest date or by storage temperature.

The percentage of greasy fruit was not measured, but observations of greasiness were made in both years. After five months storage at $1{ }^{\circ} \mathrm{C}$, fruit from the first harvest were not greasy, fruit from the second harvest were slightly greasy, and fruit from the third harvest were very greasy. All fruit stored at 3 ${ }^{\circ} \mathrm{C}$ were very greasy.

\section{Discussion}

A number of characteristics about matu- 
ration and storage behavior of 'Honeycrisp' apples have been identified in this study. The patterns in the IEC of 'Honeycrisp' apples measured at harvest did not reveal a reproducible autocatalytic increase of ethylene. The exception may be for the data from Michigan, but even here, IEC values remained below 15 $\mu \mathrm{L} \cdot \mathrm{L}^{-1}$ for about $15 \mathrm{~d}$ after an initial increase was detected before rising dramatically on

the last harvest date. In New York and Maine, the IEC differed among orchards, but it was variable over time and even declined at the later harvest dates. These results are consistent with previously published studies from different regions across the United States (Tong et al., 2003; Wargo and Watkins, 2004) and data from the 2003 season in Michigan (R. Beaudry, unpublished data). Preharvest fruit

Table 4. Effects of harvest date and storage temperature on quality attributes of 'Honeycrisp' apples harvested in the Champlain Valley, N.Y., on 10, 17, and 24 Sept. and 1 Oct. 2001 and stored in air at 0.5, 3.3, or 5.0 ${ }^{\circ} \mathrm{C}$ for 16 weeks. Data were obtained on a scale of $1=$ poor to $9=$ excellent and then multiplied by 10

\begin{tabular}{|c|c|c|c|c|}
\hline Parameter & Appearance & Texture & Flavor & $\begin{array}{c}\text { Overall } \\
\text { acceptability }\end{array}$ \\
\hline \multicolumn{5}{|c|}{ Harvest date (2002) } \\
\hline 10 Sept. & 50 & 61 & 52 & 44 \\
\hline 17 Sept. & 56 & 56 & 45 & 42 \\
\hline 24 Sept. & 69 & 62 & 52 & 46 \\
\hline 1 Oct. & 70 & 52 & 42 & 42 \\
\hline Significance & $* * *$ & NS & NS & NS \\
\hline \multicolumn{5}{|c|}{ Storage temperature $\left({ }^{\circ} \mathrm{C}\right)$} \\
\hline 0.5 & 59 & 59 & 33 & 25 \\
\hline 3.3 & 63 & 62 & 53 & 55 \\
\hline 5.0 & 62 & 53 & 38 & 41 \\
\hline Significance & NS & NS & $* * *$ & $* * *$ \\
\hline
\end{tabular}

NS,*** Nonsignificant or significant at $P \leq 0.001$, respectively.

Table 5. Incidences of soft scald, soggy breakdown, bitter pit, and decay of 'Honeycrisp' apples harvested in the Champlain Valley, N.Y., on 10, 17, and 24 Sept. and 1 Oct. 2001 and stored in air at 0.5, 3.3, or $5.0^{\circ} \mathrm{C}$ for 16 weeks. Fruit $(n=50$ to 80$)$ were evaluated after a further $7 \mathrm{~d}$ at $20{ }^{\circ} \mathrm{C}$. Means are shown as back-transformed data after analysis of arcsine transformed data.

\begin{tabular}{|c|c|c|c|c|c|}
\hline $\begin{array}{l}\text { Harvest } \\
\text { date }\end{array}$ & $\begin{array}{l}\text { Temp } \\
\left({ }^{\circ} \mathrm{C}\right)\end{array}$ & $\begin{array}{l}\text { Soft } \\
\text { scald } \\
(\%)\end{array}$ & $\begin{array}{c}\text { Soggy } \\
\text { breakdown } \\
(\%)\end{array}$ & $\begin{array}{l}\text { Bitter } \\
\text { pit } \\
(\%)\end{array}$ & $\begin{array}{c}\text { Decay } \\
(\%)\end{array}$ \\
\hline \multirow[t]{3}{*}{10 Sept. } & 0.5 & 18 & 20 & 0 & 0 \\
\hline & 3.3 & 0 & 0 & 8 & 0 \\
\hline & 5.0 & 0 & 0 & 5 & 5 \\
\hline \multirow[t]{3}{*}{17 Sept. } & 0.5 & 47 & 57 & 0 & 3 \\
\hline & 3.3 & 19 & 19 & 0 & 14 \\
\hline & 5.0 & 1 & 1 & 1 & 39 \\
\hline \multirow[t]{3}{*}{24 Sept. } & 0.5 & 56 & 75 & 0 & 1 \\
\hline & 3.3 & 11 & 12 & 0 & 1 \\
\hline & 5.0 & 1 & 0 & 5 & 5 \\
\hline \multirow[t]{3}{*}{1 Oct. } & 0.5 & 71 & 86 & 0 & 0 \\
\hline & 3.3 & 41 & 54 & 0 & 2 \\
\hline & 5.0 & 0 & 0 & 0 & 34 \\
\hline \multicolumn{6}{|l|}{ Significance } \\
\hline Harvest date $(\mathrm{H})$ & & $* *$ & $* * *$ & $* *$ & NS \\
\hline Temperature (T) & & $* * *$ & $* * *$ & $*$ & $*$ \\
\hline $\mathrm{H} \times \mathrm{T}$ & & NS & NS & $*$ & NS \\
\hline
\end{tabular}

Table 6. Fruit quality of 'Honeycrisp' apples harvested in Monmouth, Maine, and stored for 5 months in air at 1 or $3{ }^{\circ} \mathrm{C}$. Internal ethylene concentration (IEC) was measured after $1 \mathrm{~d}$ at $20^{\circ} \mathrm{C}$ and fruit firmness and soluble solids content (SSC) after $7 \mathrm{~d}$ at $20{ }^{\circ} \mathrm{C}$.

\begin{tabular}{|c|c|c|c|c|c|c|c|c|c|c|c|c|}
\hline \multirow{2}{*}{$\begin{array}{l}\text { Harvest } \\
\text { date }\end{array}$} & \multicolumn{2}{|c|}{$\begin{array}{c}\text { IEC } \\
\left(\mu \mathrm{L} \cdot \mathrm{L}^{-1}\right)\end{array}$} & \multicolumn{2}{|c|}{$\begin{array}{c}\text { Firmness } \\
(\mathrm{N})\end{array}$} & \multicolumn{2}{|c|}{$\begin{array}{l}\mathrm{SSC} \\
(\%)\end{array}$} & \multicolumn{2}{|c|}{$\begin{array}{c}\text { Soft } \\
\text { scald } \\
(\%)\end{array}$} & \multicolumn{2}{|c|}{$\begin{array}{c}\text { Flesh } \\
\text { browning } \\
(\%)\end{array}$} & \multicolumn{2}{|c|}{$\begin{array}{c}\text { Bitter } \\
\text { pit } \\
(\%)\end{array}$} \\
\hline & $1^{\circ} \mathrm{C}$ & $3{ }^{\circ} \mathrm{C}$ & $1^{\circ} \mathrm{C}$ & $3{ }^{\circ} \mathrm{C}$ & $1{ }^{\circ} \mathrm{C}$ & $3^{\circ} \mathrm{C}$ & $1{ }^{\circ} \mathrm{C}$ & $3{ }^{\circ} \mathrm{C}$ & $1^{\circ} \mathrm{C}$ & $3{ }^{\circ} \mathrm{C}$ & $1{ }^{\circ} \mathrm{C}$ & $3{ }^{\circ} \mathrm{C}$ \\
\hline \multicolumn{13}{|l|}{2002} \\
\hline 13 Sept. & 62.0 & --- & 76.3 & --- & 13.3 & --- & 0 & --- & 0 & --- & 5 & --- \\
\hline 25 Sept. & 39.1 & 185.8 & 68.2 & 68.9 & 13.5 & 13.0 & 30 & 2 & 1 & 2 & 1 & 3 \\
\hline 7 Oct. & 86.2 & 126.6 & 64.3 & 64.0 & 13.3 & 13.2 & 1 & 0 & 8 & 6 & 6 & 2 \\
\hline \multicolumn{13}{|l|}{ Significance } \\
\hline Harvest date $(\mathrm{H})$ & \multicolumn{2}{|c|}{$* *$} & \multicolumn{2}{|c|}{$* * *$} & \multicolumn{2}{|c|}{ NS } & \multicolumn{2}{|c|}{$* * *$} & \multicolumn{2}{|c|}{$*$} & \multicolumn{2}{|c|}{$* *$} \\
\hline Temperature (T) & \multicolumn{2}{|c|}{$* * *$} & \multicolumn{2}{|c|}{ NS } & \multicolumn{2}{|c|}{ NS } & \multicolumn{2}{|c|}{$* * *$} & \multicolumn{2}{|c|}{ NS } & \multicolumn{2}{|c|}{ NS } \\
\hline $\mathrm{H} \times \mathrm{T}$ & \multicolumn{2}{|c|}{$* *$} & \multicolumn{2}{|c|}{ NS } & \multicolumn{2}{|c|}{ NS } & \multicolumn{2}{|c|}{$* * *$} & \multirow{2}{*}{\multicolumn{2}{|c|}{ NS }} & \multicolumn{2}{|c|}{ NS } \\
\hline \multicolumn{11}{|l|}{2003} & & \\
\hline 19 Sept. & 25.1 & --- & 70.7 & --- & 12.1 & - & 1 & --- & 6 & -- & 2 & --- \\
\hline 29 Sept. & 22.8 & 44.8 & 68.2 & 68.3 & 12.8 & 12.7 & 1 & 0 & 3 & 0 & 0 & 3 \\
\hline 7 Oct. & 23.6 & --- & 64.8 & --- & 13.0 & --- & 4 & --- & 1 & --- & 1 & --- \\
\hline \multicolumn{13}{|l|}{ Significance } \\
\hline $\mathrm{H}$ & \multicolumn{2}{|c|}{ NS } & \multicolumn{2}{|c|}{$* *$} & \multicolumn{2}{|c|}{$*$} & \multicolumn{2}{|c|}{ NS } & \multicolumn{2}{|c|}{ NS } & & \\
\hline T (29 Sept.) & & & & & & & & & & & & \\
\hline
\end{tabular}

Ns, $, * * *, * * *$ Nonsignificant or significant at $P \leq 0.05,0.01$ or 0.001 , respectively. 
of 'Honeycrisp' in Maine usually occurs the last week of Sept., corresponding with a starch index 7 in 2002 and 8 in 2003. The harvest maturity of 'Honeycrisp' as established commercially in each region is associated with markedly different starch indices. Patterns of starch degradation appear to be affected by growing region, perhaps related to effects of climate on initiation of starch hydrolysis in apple fruit and the rates of change (Smith et al., 1979).

The lack of marked changes in SSC and titratable acidity shown in this study and elsewhere (Wargo and Watkins, 2004) suggests that their usefulness as harvest indices for 'Honeycrisp' is limited.

The relatively stable fruit firmness over a range of harvest dates and over the storage periods of 3 to 5 months in this study indicates that, unlike most apple cultivars, 'Honeycrisp', undergoes relatively little change in those cell wall components responsible for a loss in primarily shear forces commonly used as a measure of fruit firmness. Crispness, but not necessarily firmness, of 'Honeycrisp' is associated with maintenance of high turgor potential and cell wall integrity (Tong et al., 1999). Moreover, sensory tests carried out during this study indicate that differences in texture were detectable even when pressure readings were similar, indicating that pressure tests are of limited value in determining quality of this cultivar.

Soft scald and soggy breakdown were predominant storage disorders of 'Honeycrisp' in these experiments. Our data in Michigan where a single storage temperature of $0{ }^{\circ} \mathrm{C}$ was tested and in New York indicate that later harvest dates and low storage temperatures are the major factors affecting sensitivity of fruit to development of these disorders. The pattern of an increase in soft scald incidence, followed by a decrease at the later harvests in Michigan and in Maine is unusual for storage disorders, and we do not yet have an explanation. The effects of storage temperature and harvest maturity on soft scald and soggy breakdown are consistent with the view that these disorders are low temperature injuries and that their development in susceptible cultivars can be reduced by utilizing warmer storage temperatures, e.g., 2 to $3{ }^{\circ} \mathrm{C}($ Smock and Neubert, 1950; Snowdon, 1990). However, the data presented here and elsewhere (Watkins et al., 2004), together with industry experience, is that higher storage temperatures will not completely control development of the disorders in late-harvested fruit. Also, decay was generally associated with the lesions caused by soft scald, so the close association of decay with soft scald incidence is likely a result of pathogens attacking compromised or dead tissue.

Bitter pit was found in New York and Maine fruit. There was no clear trend relating bitter pit incidence to maturity at harvest for either location. This disorder is associated with low calcium and can be controlled by calcium spray programs in the field (Rosenberger et al., 2004).

Greasiness, found only in 2000 in New York, and observed, but not quantified in Maine fruit increased with increasing harvest maturity at both locations in a manner consistent with previous studies on other cultivars (Leake et al., 1989a, 1989b). This phenomenon is associated with changes in the wax and oil composition of skin (Morice and Shorland, 1973).

Collectively, our results indicate that correct harvest dates and storage temperatures are important for storage quality of 'Honeycrisp'. However, no single harvest index for aiding the decision making for harvest has emerged from the data collected from the three regions in this study. Because 'Honeycrisp' apples develop an attractive color during ripening, but undergo relatively limited softening in storage, ourcurrent recommendation is to harvest fruit on the basis of color using spot or selective picking. We also recommend use of storage temperatures of about 3 ${ }^{\circ} \mathrm{C}$ toreduce the risk of low temperature disorders. However, depending on growing region, these higher temperatures may result in undesirable levels of greasiness development. The industry was initially reluctant to use higher temperatures for 'Honeycrisp', especially because limited production and the low volumes of fruit available did not warrant separate storage facilities when temperatures close to $0{ }^{\circ} \mathrm{C}$ are used to maintain quality of most cultivars in air storage. In addition, while increasing storage temperatures can reduce incidence of the disorders, higher storage temperatures do not completely control their development in highly susceptible fruit. However, the high returns for the cultivar have encouraged storage operators to make necessary adjustments in their operations as well as applying prestorage delays which can further reduce the risk of soft scald and soggy breakdown development (Watkins et al., 2004).

\section{Literature Cited}

Anon. 1948. Ground color chart for McIntosh apples. Cornell Univ. Ext. Bul. 750.

Blanpied, G.D. and C.R. Little. 1991. Relationships among bloom dates, ethylene climacteric initiation dates, and maturity-related storage disorders of Jonathan apples grown in Australia. Postharv. Biol. Technol. 1:3-10.

Blanpied, G.D. and K.J. Silsby. 1992. Predicting harvest date windows for apples. Cornell Cooperative Ext. Information Bul. 221.

Brooks, C. and C.P. Harley.1934. Soft scald and soggy break-down of apples. J. Agr. Res. 49:55-69.

Chu, C.L. 1988. Internal ethylene concentration of 'McIntosh', 'Northern Spy', 'Empire', 'Mutsu', and 'Idared' apples during the harvest season. J. Amer. Soc Hort. Sci. 113:226-229.

Ferguson, I.B. and C.B. Watkins. 1989. Bitter pit in apple fruit. Hort. Rev. 11:289-355.

Greene, D.W. and W.R. Autio. 1990. Evaluation of ripening and fruit quality of 'Gala' and 'McIntosh' apples at harvest and following air storage. Fruit Var. J. 44:117-123.

Greene, D.W. and S.A. Weis. 2001. Evaluation and growing of Honeycrisp in New England. Compact Fruit Tree 34:100-103.

Harker, F.R., C.B. Watkins, P.L. Brookfield, M.J. Miller, S.J. Reid, P.J. Jackson, R.L. Bieleski, and T. Bartley. 1999. Maturity and regional influences on watercore development and its postharvest disappearance in 'Fuji' apples. J. Amer. Soc. Hort. Sci. 124:166-172.

Knee, M., S.M. Smith, and D.S. Johnson. 1983. Comparison of methods for estimating the onset of the respiration climacteric in unpicked apples. J. Hort. Sci. 58:521-526.

Lau, O.L., Y. Liu, and S.F. Yang. 1986. Effects of fruit detachment on ethylene biosynthesis and loss of flesh firmness, skin color, and starch in ripening 'Golden Delicious' apples. J. Amer. Soc. Hort.
Sci. 111:731-734.

Leake, A.L., S.M. Hoggett, and C.B. Watkins. 1989a. Solving the greasiness problem in Granny Smith apple fruit. Orchardist N.Z. 62(4):24-26.

Leake, A.L., S.M. Hoggett, and C.B. Watkins. 1989b. Granny Smiths revisited. Orchardist N.Z. 62(6):23.

Luby, J.J. and D.S. Bedford. 1992. Honeycrisp apple. Univ. Minn. Agr. Expt. Sta. Rpt. 225-1992 (ADMR-5877-B).

Mansour, R., A. Latche, V. Vaillant, J.-C. Pech, and M.S. Reid. 1986. Metabolism of 1-aminocyclopropane-1-carboxylic acid in ripening apple fruits. Physiol. Plant. 66:495-502.

Morice, I.M. andF.B. Shorland. 1973. Composition of the surface waxes of apple fruits and changes during storage. J. Sci. Food Agr. 24:1331-1339.

Pierson, C.F., M.J. Ceponis, and L.M. McColloch. 1971. Market diseases of apples, pears, and quinces. USDA Hndbk. 376.

Plagge, H.H., T.J. Maney, and B.S. and Pickett. 1935. Functional diseases of the apple in storage. Iowa Agr. Expt. Sta. Bul. 329:37-79.

Plagge, H.H. and T.J. Maney. 1937. Factors influencing the development of soggy break-down in apples. J. Agr. Res. 55:739-763.

Rosenberger, D., J. Schupp, C. Watkins, K. Iungerman, S. Hoying, D. Straub, and L. Cheng. 2001. Honeycrisp: Promising profit maker or just a problem child? N.Y. Fruit Quartr. 9(3):9-13.

Rosenberger, D. A., J.R. Schupp, S.A. Hoying, L. Cheng, and C.B. Watkins. 2004. Controlling bitter pit in 'Honeycrisp' apples. HortTechnology 14:342-349.

Sfakiotakis, E.M. and D.R. Dilley. 1973. Internal ethylene concentrations in apple fruits attached to or detached from tree. J. Amer. Soc. Hort. Sci. 98:501-503.

Shewfelt, R.L. 1993. Measuring quality and maturity, p. 100-124. In: R.L.Shewfelt and S.E. Prussia (eds.). Postharvest handling: a systems approach. Academic Press, San Diego, Calif.

Smith, R.B., E.C. Lougheed, E.W. Franklin, and I. McMillan. 1979. The starch iodine test for determining stage of maturation in apples. Can. J. Plant Sci. 59:725-735.

Smock, R.M. and A.M. Neubert. 1950. Economic crops. vol. 2. Apples and apple products. Interscience Publ., Inc., New York.

Snowdon, A.L. 1990. A color atlas of post-harvest diseases and disorders of fruits and vegetables. vol. 1. CRC Press, Inc, Boca Raton, Fla.

Tong, C., D. Krueger, Z. Vickers, D. Bedford, J. Luby, A. El-Shiekh, K. Shackel, and H. Ahmadi. 1999. Comparison of softening-related changes during storage of 'Honeycrisp' apples, itsparents, and 'Delicious'. J. Amer. Soc. Hort. Sci. 124:407-415.

Tong, C., D.S. Bedford, J.J. Luby, F.M. Propsom, R.M. Beaudry, J.P. Mattheis, C.B. Watkins, and S.A. Weis. 2003. Location and temperature effects on soft scald in 'Honeycrisp' apples. HortScience 38:1153-1155.

Wargo, J.M. and C.B.Watkins. Maturity and storage quality of 'Honeycrisp' apples. HortTechnology 14:496-499.

Watkins, C.B. and D.A. Rosenberger. 2002. Cornell Fruit Handling and Storage Newsletter. http:// www.hort.cornell.edu/department/faculty/watkins/extpubs.html.

Watkins, C.B., J.H. Bowen, and V.J. Walker. 1989. Assessment of ethylene production by apple cultivars in relation to commercial harvest dates. N.Z. J. Crop Hort. Sci. 17:327-331.

Watkins, C.B., J.F. Nock, S.A. Weis, S. Jayanty, and R.M. Beaudry. 2004. Storage temperature, diphenylamine, and pre-storage delay effects on soft scald, soggy breakdown and bitter pit of 'Honeycrisp' apples. Postharv. Biol. Technol. 32:213-221. 